OPEN ACCESS

Edited by:

Seung Kew Yoon Catholic University of Korea,

South Korea

Reviewed by:

Davide Angeletti,

University of Gothenburg, Sweden

Antonio Bertoletti,

Duke-NUS Medical School, Singapore

*Correspondence:

Mengji Lu

mengji.lu@uni-due.de

Specialty section:

This article was submitted to

Viral Immunology,

a section of the journal

Frontiers in Immunology

Received: 19 July 2019 Accepted: 12 September 2019 Published: 24 September 2019

Citation:

Ma Z, Zhang E, Gao S, Xiong Y and Lu M (2019) Toward a Functional Cure for Hepatitis B: The Rationale and

Challenges for Therapeutic Targeting of the B Cell Immune Response.

Front. Immunol. 10:2308 doi: 10.3389/fimmu.2019.02308

\section{Toward a Functional Cure for Hepatitis B: The Rationale and Challenges for Therapeutic Targeting of the B Cell Immune Response}

\author{
Zhiyong Ma ${ }^{1}$, Ejuan Zhang ${ }^{2}$, Shicheng Gao ${ }^{1}$, Yong Xiong ${ }^{1}$ and Mengji Lu ${ }^{3 *}$ \\ ${ }^{1}$ Department of Infectious Diseases, Zhongnan Hospital of Wuhan University, Wuhan, China, ${ }^{2}$ Wuhan Institute of Virology, \\ Chinese Academy of Sciences, Wuhan, China, ${ }^{3}$ Institute of Virology, University Hospital Essen, University of Duisburg-Essen, \\ Essen, Germany
}

The central role of the cellular immune response in the control and clearance of the hepatitis B virus (HBV) infection has been well-established. The contribution of humoral immunity, including $B$ cell and antibody responses against HBV, has been investigated for a long time but has attracted increasing attention again in recent years. The anti-HBs antibody was first recognized as a marker of protective immunity after the acute resolution of the HBV infection (or vaccination) and is now defined as a biomarker for the functional cure of chronic hepatitis B (CHB). In this way, therapies targeting HBV-specific B cells and the induction of an anti-HBs antibody response are essential elements of a rational strategy to terminate chronic HBV infection. However, a high load of HBsAg in the blood, which has been proposed to induce antigen-specific immune tolerance, represents a major obstacle to curing CHB. Long-term antiviral treatment by nucleoside analogs, by targeting viral translation by siRNA, by inhibiting HBsAg release via nucleic acid polymers, or by neutralizing $\mathrm{HBsAg}$ via specific antibodies could potentially reduce the HBsAg load in $\mathrm{CHB}$ patients. A combined strategy including a reduction of the HBsAg load via the above treatments and the therapeutic targeting of $B$ cells by vaccination may induce the appearance of anti-HBs antibodies and lead to a functional cure of $\mathrm{CHB}$.

Keywords: hepatitis B virus, functional cure, B cell response, therapeutic vaccine, chronic hepatitis B

\section{INTRODUCTION}

It is estimated that more than 250 million people worldwide are chronically infected with the hepatitis B virus (HBV), and over 887,000 deaths are caused by HBV infection annually due to the disease's complications, such as cirrhosis and hepatocellular carcinoma (HCC) $(1,2)$. Up to 95\% of adults are spontaneously cleared of the virus after an acute self-limiting HBV infection, while $90 \%$ of newborns develop a chronic infection. The outcome of acute HBV infection is mainly determined by the strength and breadth of the host's adaptive immune responses against the virus (3). An acute resolving HBV infection is always associated with multi-specific and vigorous $\mathrm{HBV}$-specific $\mathrm{CD}^{+} \mathrm{T}$ cell responses (4-6), which are functionally exhausted during chronic HBV infection partly due to the high load of viral antigens in the blood (7-9). While the central role of the $\mathrm{CD}^{+} \mathrm{T}$ cell response in the control of $\mathrm{HBV}$ infection is well-established, the contribution 
of humoral immunity (including B cell and antibody responses) has largely been neglected. Recently, several groups have addressed this question and highlighted that $\mathrm{HBV}$-specific $\mathrm{B}$ cells are present in the blood and liver but functionally impaired during chronic HBV infection (10-12). Moreover, the level of the serum hepatitis B core antigen ( $\mathrm{HBcAg}$ ) antibody (anti-HBc) was to be found positively correlated with $\mathrm{HBV}$-induced liver disease or inflammation $(13,14)$ and predicted the therapeutic efficacy of peginterferon (Peg-IFN) and nucleos(t)ide analogs (NAs) in hepatitis $\mathrm{B}$ e antigen ( $\mathrm{HBeAg}$ )-positive chronic hepatitis B (CHB) patients (15-17).

Currently, Peg-IFN and NAs are approved and recommended as first-line therapies for $\mathrm{CHB}$ in clinical guidelines (18). However, it is difficult to cure $\mathrm{CHB}$ with these drugs, which means achieving sustained undetectable HBV surface antigen (HBsAg) and HBV DNA levels in serum, with or without the appearance of antibodies to the HBsAg (anti-HBs) (19). Anti-HBs antibodies were initially recognized as a diagnostic marker, indicating protective immunity after acute-resolving HBV infection or vaccination. Now, they are considered a biomarker for a functional cure of CHB. Thus, the therapeutic targeting of HBV-specific $\mathrm{B}$ cells and the induction of an anti-HBs antibody response are essential parts of a rational strategy to cure CHB. Knowledge of the features of $\mathrm{B}$ cell responses against HBV during acute and chronic viral infections is needed to rationally design strategies that target $B$ cells in CHB patients. In this review, we summarize the currently available information about host B-cell and antibody responses in HBV infections, as well as their relationship with $\mathrm{HBV}$ pathogenesis, the pivotal role of HBsAg in HBV pathogenesis, and immunotherapeutic approaches to induce HBV-specific immunity and anti-HBs antibodies in chronic HBV infection.

\section{DOES B CELL-MEDIATED HUMORAL IMMUNITY PLAY A KEY ROLE IN HBV CONTROL AND CLEARANCE?}

Unlike HBV-specific $\mathrm{CD}^{+} \mathrm{T}$ cells, which can be detected by tetramer staining ex vivo or after in vitro expansion, the specific $B$ cells that target HBV have only been studied recently by using fluorochrome-labeled HBV proteins (10-12). However, several clinical observations suggest that $\mathrm{B}$ cell response may have an important role in the control of HBV infection. Rituximab, an antibody of $\mathrm{CD} 20$, is widely used to deplete $\mathrm{B}$ cells during chemotherapy in B cell lymphomas or autoimmune diseases. If these patients have a previously controlled HBV infection, the clinical application of rituximab may cause HBV reactivation, indicating that $\mathrm{B}$ cell responses against $\mathrm{HBV}$ are essential to maintaining effective host immune control over HBV (20-22). Moreover, anti-HBs positivity is associated with a decreased risk of HBV reactivation in these patients, suggesting that antiHBs may also prevent the HBV reactivation (23). Indeed, anti$\mathrm{HBs}$ are known as protective antibodies, which block HBV entry into host hepatocytes and clear infectious HBV particles in vivo (24). Several B cell epitopes have been identified on three large, middle, and small HBV surface proteins. One welldefined region called the a-determinant comprises a number of conformation-dependent epitopes, which are located within the first loop amino acid (aa)124-137 and the second loop aa139-147 of HBsAg. The majority of anti-HBs antibodies developed by vaccination recognize the a-determinant. Another important region is located within the sequence aa21-47 of the HBV large surface protein, which contains the binding site of the HBV cellular receptor, sodium-taurocholate co-transporting polypeptide (NTCP). Thus, the antibodies specific to this region may have potent neutralization activities $(24,25)$. These studies imply that the B cell-mediated humoral immune response represents an important component in the sustained control of HBV infection.

However, whether the B cell-mediated immune response directly influences the HBV immunopathogenesis remains unclear. In patients with $\mathrm{HBeAg}$-positive $\mathrm{CHB}$, the appearance of the HBeAg antibody (anti-HBe) has been known to be an indicator of a low level of hepatic HBV replication, which is usually associated with the clinical remission of liver disease and a favorable outcome (2). Recently, the level of the hepatitis B core antigen ( $\mathrm{HBcAg}$ ) antibody (anti- $\mathrm{HBc}$ ) in $\mathrm{CHB}$ patients was found to be positively correlated with $\mathrm{HBV}$-induced liver disease or inflammation in CHB patients $(13,14)$. Consistently, the baseline anti- $\mathrm{HBc}$ level was found to be a useful predictor of Peg-IFN and NAs therapy efficacy in HBeAg-positive CHB patients (1517). In a recent study, a higher baseline anti-HBc titer could predict a higher rate of spontaneous HBeAg seroconversion in $\mathrm{HBeAg}$-positive children with a normal alanine aminotransferase (ALT) level. The anti-HBc level could reflect the strength of the anti-HBV immune response in the HBeAg-positive normal ALT phase of CHB (26). A study using liver samples from different phases of $\mathrm{CHB}$ was performed to determine the intrahepatic gene signatures. The results demonstrated that a high up-regulation of immunoglobulin-encoding genes and B-cell function-related genes was found in the immune active phase compared with the immune tolerant and inactive carrier phases (27). Moreover, a powerful $B$ cell response with a massive accumulation of plasma cells secreting IgG and IgM to $\mathrm{HBcAg}$ was found in the liver of two patients with HBV-related acute liver failure $(28,29)$. In a very recent study, Le Bert et al. showed that the frequencies of HBcAg-specific B cells, but not HBsAgspecific $B$ cells, were temporarily increased in the blood during hepatic flares in four CHB patients (12), again indicating a possible link between $\mathrm{HBcAg}$-specific B cells and liver damage in $\mathrm{CHB}$ patients. These data suggest that humoral immunity may participate in the pathogenesis of $\mathrm{HBV}$ infection. It remains to be investigated whether the anti-HBc antibody response is, indeed, the initial trigger of the host's immune attack against $\mathrm{HBV}$ in the liver, thereby leading to inflammation and immunopathological processes in chronically HBV infected patients.

Given the importance of anti-HBs in preventing and curing HBV infection, several groups have attempted to detect the HBsAg-specific memory B cell response using different methods in vaccinated people and $\mathrm{CHB}$ patients. An HBs-ELISPOT assay has been developed to identify anti-HBs secreting $\mathrm{B}$ cells by culturing enriched $\mathrm{CD} 19^{+}$cells with stimulation of 
CD40-CD40L for 5 days $(30,31)$. Another group directly detected HBsAg-specific memory B cells by FACS analysis ex vivo utilizing $\mathrm{HBsAg}$-conjugated microbeads in an enriched $\mathrm{CD}_{1}{ }^{+}$cell population (32). Apparently, the frequency of HBsAg-specific memory B cells was extremely low. These two methods efficiently detected HBsAg-specific B cells in HBsAgvaccinated individuals but not in patients with chronic HBV infection. Recently, two groups utilized fluorochrome-labeled recombinant HBsAg as "bait" to detect and characterize HBsAgspecific B cells by flow cytometric analysis ex vivo in HBVinfected patients $(10,11)$. Similar results were obtained from the two studies, demonstrating that the frequencies of $\mathrm{HBsAg}$ specific $B$ cells in the blood were similar in acute, chronic, and resolved HBV infection, and have no correlation with the serum levels of HBsAg, HBV DNA, and ALT. The phenotype of HBsAg-specific B cells from CHB patients resembled "atypical memory B cells" that are characterized by a low expression of CD21 and CD27 but a high expression of inhibitory markers, such as programmed cell death receptor-1 (PD-1) and the transcription factor, T-bet. Moreover, HBsAg-specific B cells from $\mathrm{CHB}$ patients were unable to mature into anti-HBssecreting cells in vitro. However, their function could be partially restored by specific culture conditions, such as a PD-1 blockade or the addition of IL-2, IL-21, and CD40L-expressing feeder cells $(10,11,33)$. The dysfunction and phenotype change of $\mathrm{B}$ cell responses during chronic HBV infection were also confirmed by other groups (34-36). Le Bert et al. conducted a more comprehensive characterization of $\mathrm{B}$ cell responses against HBsAg and HBcAg in CHB patients (12). They found that $\mathrm{HBcAg}$-specific $\mathrm{B}$ cells are present at a higher frequency than $\mathrm{HBsAg}$-specific B cells in CHB patients. Furthermore, nearly all $\mathrm{HBcAg}$-specific B cells are the IgG+ memory B cell phenotype and mature efficiently into antibody-secreting cells in vitro. The differences in the phenotype and function between HBsAgand $\mathrm{HBcAg}$-specific $\mathrm{B}$ cells in the same patient suggest that a high level of HBsAg might cause dysfunctional programming of HBsAg-specific B cells through persistent stimulation (12). The characterization of the HBsAg-specific $B$ cell response in chronic HBV infection facilitates the development of strategies that target $\mathrm{B}$ cell responses to induce anti-HBs antibodies for the functional cure of CHB.

Using highly sensitive immunoassays, previous studies demonstrated the existence of anti-HBs antibodies in CHB patients, but they are mainly detected as being complexed to HBsAg $(37,38)$. This result may suggest that anti-HBs antibodies are produced by HBV-specific B cells in chronic HBV infection but masked by the high level of circulating HBsAg. This may lead to the coexistence of HBsAg and antiHBs antibodies in CHB patients when their specificity does not match, as shown by several studies $(39,40)$. In some cases, the appearance of anti-HBs antibodies alone may clear HBsAg in the peripheral blood, but they do not terminate chronic HBV infection in the liver (41). Thus, the HBVspecific $B$ cell response is an integrative part of the host's defense and contributes to HBV pathogenesis, clearance, and protective immunity but is not sufficient to control HBV infection alone.

\section{THE EFFICACY OF ANTIBODY-MEDICATED IMMUNOTHERAPY OR TRIGGERING B-CELL RESPONSE TO CURE CHRONIC HEPATITIS B: RESULTS FROM CLINICAL STUDIES}

Polyclonal hepatitis B immunoglobulins (HBIG) are prepared from the pooled plasma of vaccine recipients with a high titer of anti-HBs antibodies. HBIG has been widely used in clinical environments for post-exposure prophylaxis against HBV infection in neonates born to HBsAg carriers (42), as well as in HBV infected liver transplant patients (43). The success of HBIG in these conditions raises the possibility of antibodymediated immunotherapy against chronic HBV infection (25). Indeed, three pioneering studies tested the efficacy of antiHBs monoclonal antibodies or HBIG in CHB patients, alone or in combination with alpha-interferon (44-46). All these studies demonstrated the temporary reduction of HBsAg and HBV DNA after a high dose of anti-HBs antibody treatment, though the long-term clearance of HBsAg was not observed. Particularly, in a phase I clinical study, a mixture of two monoclonal antibodies, named $\mathrm{HBV}-\mathrm{AB}^{\mathrm{XTL}}$, was well-tolerated and led to a significant reduction of serum HBsAg and HBVDNA after repeat administration (45). A phase II clinical study was also conducted to evaluate the therapeutic efficacy of a combination of $\mathrm{HBV}-\mathrm{AB}^{\mathrm{XTL}}$ with antiviral treatment in chronic HBV-infected patients. However, the results have not yet been released. In a recent pilot study, eight lamivudinetreated CHB patients received monthly HBIG injections followed by an $\mathrm{HBV}$ vaccination, which led to a significant decrease of serum HBsAg in half of the patients after 1-year of treatment (47). Importantly, three patients became anti-HBs positive, thereby achieving the goal of a functional cure (47). This study implied that a combination strategy with antiviral treatment and antibody mediated immunotherapy, followed by triggering a B cell response through vaccination may lead to a sustained loss of HBsAg and a functional cure for CHB. However, further clinical trials are needed to test and confirm the therapeutic efficacy of this combination strategy.

As mentioned above, the majority of patients with persistent HBV infections are always linked with the dysfunction of HBV-specific T-cell and B-cell responses (3). During the past two decades, repeated attempts have been made to restore efficient HBV-specific T-cell and B-cell responses in such patients, using conventional or modified HBV vaccines. These attempts have been called "therapeutic vaccination," with the goal of stopping chronic HBV infection. Using a mammalian cell expressed recombinant Pre-S2/S protein, Pol et al. were the first to demonstrate that vaccination with this protein leads to a significant decrease, or the disappearance, of serum HBV DNA in $50 \%$ of treated patients in a pilot study (48). However, the treatment's therapeutic efficacy was not confirmed in a multicenter study including $118 \mathrm{CHB}$ patients (49). Six immunizations with a vaccine consisting of recombinant $\mathrm{HBsAg}$ with anti-HBs immune complexes (HBsAg-IC) induced a higher 
rate of $\mathrm{HBeAg}$ seroconversion in $\mathrm{HBeAg}$-positive $\mathrm{CHB}$ patients compared to the control group (50). However, in a larger scale phase III study, the therapeutic efficacy of HBsAg-IC was not confirmed, though the vaccination was performed at a high dose and given 12 times (51). Antiviral therapy with NAs could partially restore the $\mathrm{HBV}$-specific $\mathrm{T}$ cell response in $\mathrm{CHB}$ patients (52-54), so it is rational to enhance the efficacy of therapeutic vaccination through combination with antiviral therapy.

Co-administration of the $\mathrm{HBsAg} / \mathrm{AS02B}$ adjuvant candidate vaccine with lamivudine induced a vigorous HBsAg-specific $\mathrm{T}$ cell response in patients with $\mathrm{HBeAg}$ positive $\mathrm{CHB}$. However, this vaccination strategy did not demonstrate superior clinical efficacy to improve the $\mathrm{HBeAg}$ seroconversion rate when compared to treatment with lamivudine alone (55). In another study, $180 \mathrm{HBeAg}$ positive patients were randomly assigned into three groups to receive a mammalian cell-derived vaccine containing PreS1/PreS2/S proteins (named Sci-B$\mathrm{Vac}^{\mathrm{TM}}$ ), lamivudine monotherapy, or a combination treatment. The PreS1/PreS2/S vaccine showed improved immunogenicity and could rapidly induce higher levels of anti-HBs antibodies than the conventional HBsAg vaccines in previous studies (56, 57). The results demonstrated that a combination treatment with the PreS1/PreS2/S vaccine and lamivudine led to enhanced efficacy in viral inhibition, although the HBeAg seroconversion rate was not different. Moreover, anti-HBs antibodies were detected in 55/120 vaccine recipients. The appearance of anti-HBs was associated with significantly higher $\mathrm{HBeAg}$ seroconversion rates and a greater suppression of HBV DNA levels in these patients (58). This study highlighted that antiHBs antibodies could be induced by therapeutic vaccination and might play an important role in the suppression of viral replication.

Taken together, these various clinical trials mentioned suggest that antibody-mediated immunotherapy or targeting B cells by therapeutic vaccination may reconstitute the HBVspecific immune response and lead to a reduction of HBV replication in some CHB patients. However, the efficacy of these treatments is low, and further efforts are needed to optimize the therapeutic efficacy.

\section{THE PIVOTAL ROLE OF HBSAG IN THE PATHOGENESIS OF CHRONIC HBV INFECTION AND THE SUPPRESSION OF EFFECTIVE HOST IMMUNITY}

Following viral entry into the hepatocytes, the HBV relaxed circular DNA (rcDNA) is converted into a covalently closed circular DNA (cccDNA) minichromosome, which is serviced as a template for subsequent transcription and translation of viral proteins. Many viral proteins were synthesized and secreted into the serum, including three $\mathrm{HBV}$ surface proteins and the hepatitis $\mathrm{B}$ core-related antigen ( $\mathrm{HBcrAg})$, which contains HBeAg (59). The serum level of HBcrAg has been shown to correlate with $\mathrm{HBV}$ cccDNA transcriptional activity in $\mathrm{CHB}$ patients $(60,61)$. Furthermore, CHB patients with a persisting high level of HBcrAg during antiviral therapy have an increased risk to develop HCC despite sustained viral suppression via longterm NAs treatment $(62,63)$. The clinical significance of HBsAg quantification during chronic HBV infection and antiviral treatment has been studied extensively (64-66). The HBsAg level is the highest in the immune tolerance phase and starts to decline slowly during the immune clearance phase. The HBsAg level progressively decreases after spontaneous or antiviral therapy induced HBeAg seroconversion. Accumulating evidence suggests that high levels of HBsAg may have an immunosuppressive role on both innate and adaptive immunity against HBV (6769). Indeed, HBsAg has been shown to suppress innate hepatic immunity by inhibiting the toll-like receptor (TLR) mediated signal pathways in Kupffer cells (KCs) and sinusoidal endothelial cells (LSECs) $(70,71)$. The function of myeloid dendritic cells (DCs) was also impaired to stimulate $\mathrm{T}$ cell responses in the presence of HBsAg in vitro (72). However, in another study, the DCs isolated from CHB patients showed a normal ability to stimulate the expansion of autologous $\mathrm{HBV}$-specific T cells through the cross presentation of circulating HBsAg (73). The available results about the HBsAg-mediated suppression of innate immunity need to be carefully interpreted, because the majority of experiments were performed in vitro. In general, $\mathrm{CHB}$ patients are immunologically intact and do not show a higher susceptibility to bacterial or other opportunistic infections. The dysfunction and exhaustion of HBV-specific $\mathrm{CD} 8^{+} \mathrm{T}$ cell responses is a hallmark of chronic HBV infection. The high load of circulating and hepatic HBsAg may contribute to the impairment of HBsAg-specific $\mathrm{CD} 8^{+} \mathrm{T}$ cell response through persistent antigen stimulation (74-76). Moreover, HBsAg may suppresses $\mathrm{T}$ cell responses by promoting the differentiation of monocytes into myeloid-derived suppressor cells (MDSCs) and enhance the regulatory $\mathrm{T}$ cell response $(77,78)$. In a woodchuck hepatitis virus (WHV) transgenic mouse model, the high level of virus replication and protein expression in male mice induced the expansion of intrahepatic regulated $\mathrm{T}$ cells, leading to the impairment of WHV-specific $\mathrm{CD} 8^{+} \mathrm{T}$ cell responses and genderrelated differences in the outcomes of viral infection (79). As mentioned above, a high level of HBsAg might lead to the dysfunctional differentiation of HBsAg-specific B cells, but not $\mathrm{HBcAg}$-specific B cells in CHB patients (12). These studies demonstrated that the high HBsAg load may induce HBsAgspecific immune tolerance through different mechanisms and may represent a main obstacle in curing CHB (Figure 1).

Several studies demonstrated that quantitative baseline HBsAg levels and their changes during the early phase of antiviral therapy could predict therapeutic efficacy, as well as the clearance of HBsAg in CHB patients $(64,65,80-83)$. Moreover, lower levels of serum HBsAg at the end of antiviral therapy were associated with a higher rate of HBsAg loss in HBeAg-negative CHB patients after the cessation of long term NAs treatment (84, 85). Although NAs treatment efficiently inhibits HBV replication, it has little effect on the secretion and clearance of $\mathrm{HBsAg}$ $(86,87)$. Peg-IFN therapy may increase the rate of HBsAg loss in low level HBsAg patients, which, in previous studies, has been highlighted in both switch to or add-on strategies combining IFN and NAs to cure CHB (88-90). In patients experiencing HBsAg seroclearance, the Peg-IFN therapy or a cessation of 


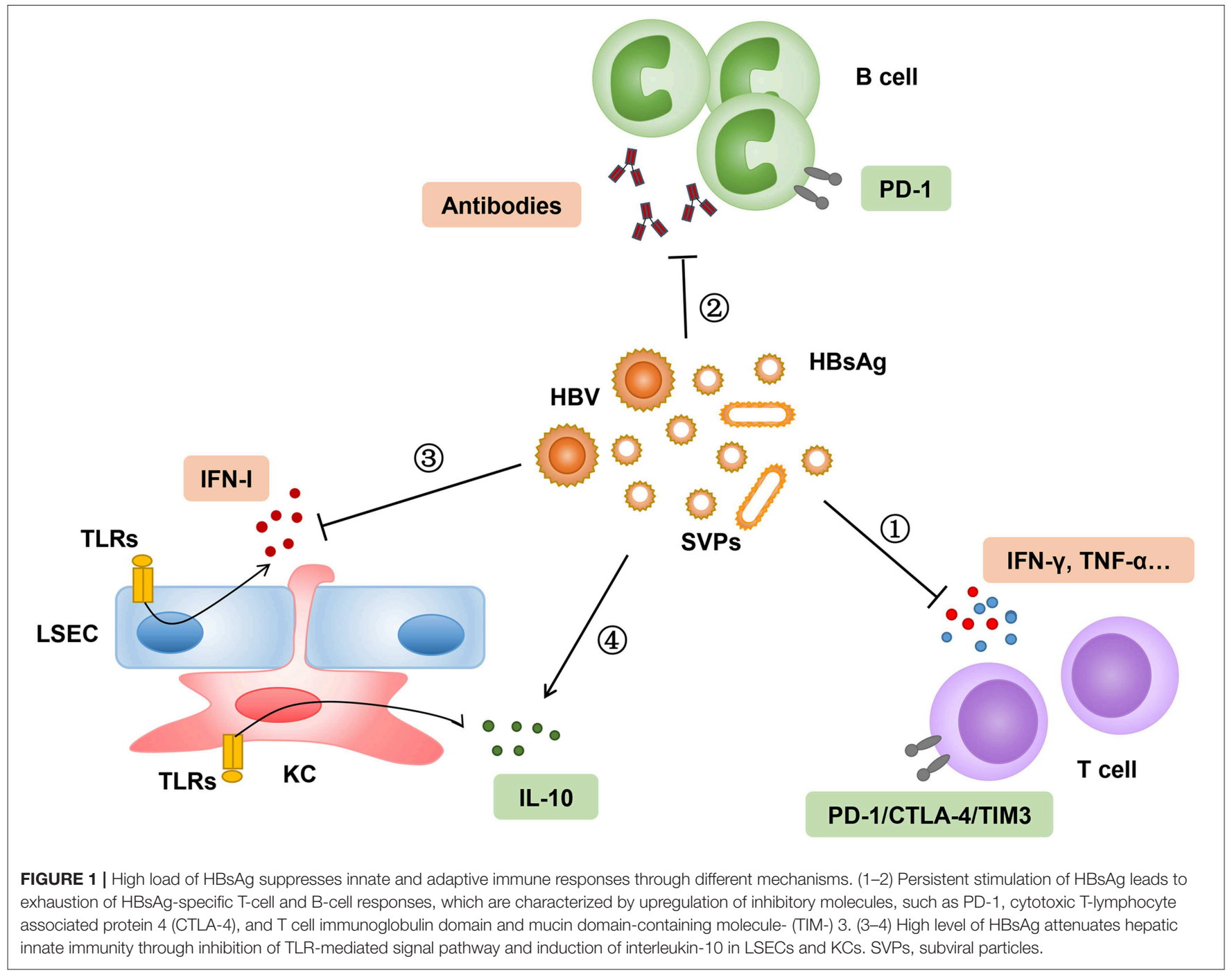

NAs treatment enhanced the natural killer cell's functionality and increased HBV-specific T cell responsiveness (90-94). These results suggest that a sequential combinatorial therapy should ideally cause a precipitous decrease in HBsAg that, when followed by an immunomodulatory therapy, leads to sustained HBsAg loss (95).

\section{HOW TO OPTIMIZE THE THERAPEUTIC EFFICACY OF STRATEGIES TARGETING B CELL RESPONSES IN CHB PATIENTS}

Due to the low efficacy of therapeutic vaccination targeting B cell responses in chronic HBV infection, we need to optimize the efficacy of this strategy to achieve a functional cure for $\mathrm{CHB}$. Several approaches, including the reduction of circulating HBsAg, improvement of B-cell targeting vaccines, a combination with immunomodulation, and a rational selection of patients could be employed to boost the therapeutic efficacy of B cell targeting vaccination in $\mathrm{CHB}$ patients.
Currently, long-term NAs treatment in $\mathrm{CHB}$ patients can lead to a gradual decrease in the serum level of HBsAg. However, only a few patients can reach a significant decrease in serum HBsAg $(86,87)$. Thus, we need more potent strategies to reduce the serum level of HBsAg. Several approaches were developed to allow a temporary reduction of circulating $\mathrm{HBsAg}$, including targeting viral translation via siRNA, inhibiting HBsAg release via nucleic acid polymers (NAPs), or neutralizing HBsAg with specific antibodies (Figure 2) (68). Recently, an RNA interference based therapeutic agent ARC-520 has been developed. ARC-520 shows a strong efficacy in reducing HBsAg levels in treatmentnaïve $\mathrm{CHB}$ patients who are positive for $\mathrm{HBeAg}$. However, their therapeutic efficacy is compromised in patients who are HBeAgnegative or have received long-term therapy with NAs $(96,97)$. Moreover, the clinical development of ARC-520 was put on hold by the U.S. Food and Drug Administration (FDA) due to the delivery vehicle EX1, which probably led to the deaths of nonhuman primates in another study (98). NAPs are single stranded phosphorothioate oligonucleotides that can block viral entry in many viruses, including the hepatitis $B$ and hepatitis $D$ virus 


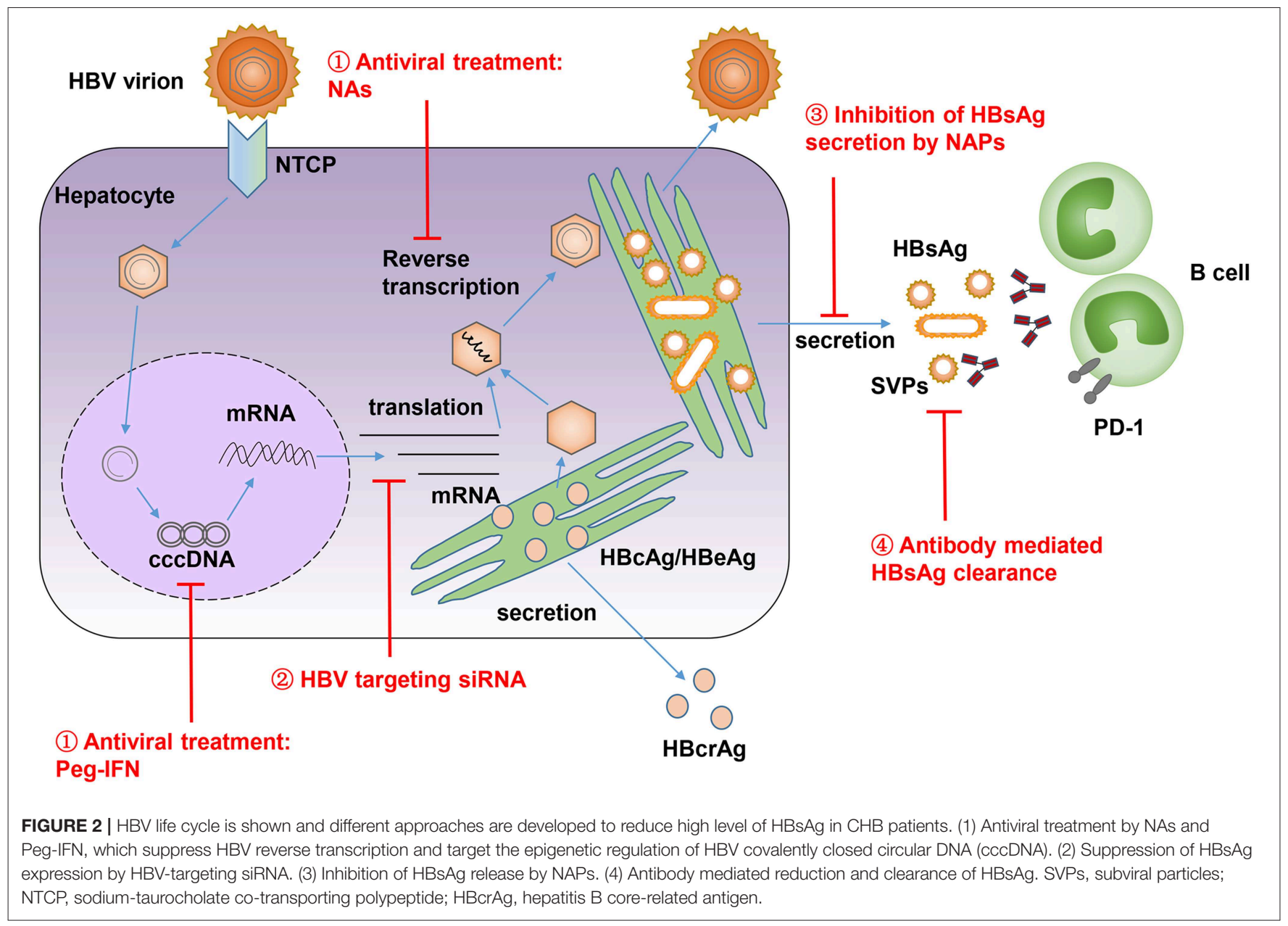

(HDV), and also have the unique ability to inhibit the release of HBsAg from HBV-infected hepatocytes (99, 100). One NAP named REP 2139 was selected and evaluated in clinical studies for its therapeutic efficacy in CHB patients $(101,102)$. In an open label, non-randomized study, weekly intravenous administration of REP 2139 led to a dramatic decrease of serum HBsAg and HBV DNA in $12 \mathrm{HBeAg-positive} \mathrm{CHB} \mathrm{patients,} \mathrm{accompanied}$ by HBsAg seroconversion (101). In another study with $12 \mathrm{HBV}$ and HDV co-infection patients, the combination of REP 2139 and peg-IFN led to a reduction of HBsAg by 2-7 logs and undetectable HDV RNA in 11 patients during therapy. One year after treatment, five patients maintained negative HBsAg, five patients had high titer anti-HBs, and seven patients remained HDV RNA negative (102). These results suggest that REP 2139 has a strong ability to decrease circulating HBsAg. However, the treatment's efficacy and side effects should be further evaluated in larger scale, blind, and randomized or real-world studies. The efficacy of specific antibody mediated reduction of HBsAg has been described in a previous section of this review. It is shown that using HBIG or monoclonal antibodies against HBsAg can efficiently decrease the serum level of HBsAg in CHB patients (44-47). In addition, high affinity human anti-HBs and antiPre-S1-monoclonal antibodies have been developed recently, and these antibodies have shown an excellent ability to efficiently clear circulating HBsAg in different mouse models (103-106). These studies emphasize the new interest in developing neutralizing antibodies as a therapeutic strategy to reduce circulating HBsAg.

Besides the reduction of circulating HBsAg to overcome immune tolerance in $\mathrm{CHB}$ patients, the improvement of B-cell targeting vaccines is the second step to optimize the therapeutic efficacy of this combination strategy. Therapeutic vaccination with conventional yeast derived HBsAg vaccines showed limited efficacy for HBsAg seroclearance in $\mathrm{CHB}$ patients, even when combined with antiviral treatment $(55,107)$. New generation $\mathrm{HBV}$ vaccines containing one (PreS2) or two (PreS1 or PreS2) additional envelope proteins have been developed in transfected mammalian cells. Compared with conventional vaccines, new generation vaccines display more immunogenic properties and rapidly induce higher levels of anti-HBs antibodies both in healthy individuals and in non-responders to yeast-derived vaccines $(49,57,108)$. As described in the previous section of this review, the PreS2 containing HBV vaccine had limited therapeutic efficacy in $\mathrm{HBeAg}$ positive $\mathrm{CHB}$ patients in the absence of antiviral treatment $(49,109,110)$. In another study, a PreS2-S vaccine combined with IFN-alpha- $2 \mathrm{~b}$ showed a better potential benefit in children with $\mathrm{CHB}$ than IFN-alpha-2b 
monotherapy (111). In contrast, the PreS1-PreS2-S vaccine Sci$\mathrm{B}-\mathrm{Vac}^{\mathrm{TM}}$ induced anti-HBs antibodies in nearly $50 \%$ of vaccine recipients in $\mathrm{HBeAg}$ positive $\mathrm{CHB}$ patients, even though these antibodies had a poor ability to neutralize the circulating HBsAg (58). However, the appearance of anti-HBs was associated with significantly higher $\mathrm{HBeAg}$ seroconversion rates and a greater suppression of HBV DNA levels in these patients (58). A nasal vaccine candidate (NASVAC), comprising $\mathrm{HBsAg}$ and $\mathrm{HBcAg}$, has been shown to be safe and highly immunogenic in healthy volunteers (112). The administration of NASVAC through intranasal and subcutaneous routes led to sustained negative HBV DNA in 50\% patients with CHB (113). In a phase III clinical study, the therapeutic efficacy of NASVAC was comparable to Peg-IFN in reducing HBV DNA under the limits of detection (114). It is necessary to further confirm the therapeutic efficacy of NASVAC on a large scale and in multicenter studies. Current studies have demonstrated the importance of improving the therapeutic efficacy of B-cell targeting vaccines.

The crosstalk of TLR7/9 and the B cell receptor (BCR) signal pathway in B cells has been previously described; this crosstalk may modulate the $B$ cell's response to foreign or endogenous antigens $(115,116)$. The stimulation of B cells with a TLR7 ligand and antigen induced a more robust increase in germinal center B cells, plasmablasts, plasma cells, and serum antibodies, compared to their cohorts who received antigen alone (117). A similar intrinsic signal pathway via TLR9 in B cells was also described. This pathway increased production of IgG, in particular, with a shift to the IgG2a subclass $(118,119)$. These results support the use of TLR7/9 ligands as adjuvants to enhance the therapeutic efficacy of B-cell targeting vaccination (120). Indeed, the immunogenicity of HBsAg was enhanced by a mixture of TLR9 agonists CPG 7909 and 1018 ISS. New vaccines induced a higher titer of anti-HBs accompanied by increased avidity through modulation of the late affinity maturation process (121-124). Importantly, this new vaccine formula proved more effective in immune-suppressed populations (125-127). Further studies are needed to explore the therapeutic efficacy of these improved vaccines on $\mathrm{CHB}$ patients.

The lessons from clinical studies suggest that patients with low levels of HBsAg easily reach the goal of HBsAg loss after ceasing long-term NAs treatment $(84,85)$ or switching to PegIFN therapy $(82,83)$. Thus, the rational selection of patients with low levels of serum HBsAg after long term NAs treatment could be employed to optimize the therapeutic efficacy of B cell targeting vaccination. Indeed, in a recent study, conventional HBsAg-based vaccination in $20 \mathrm{HBeAg}$-negative patients with HBsAg $<1,000 \mathrm{IU} / \mathrm{ml}$, resulted in a significant HBsAg decline in 14 patients and HBsAg loss in 2 patients (128). In another study, the switch from long-term entecavir (ETV) treatment to a combined therapy with IFN-alpha-2b, HBsAg-based vaccination, and IL-2 resulted in a higher HBsAg loss rate (9.38\%) compared to IFN-alpha-2b (3.03\%) alone or continued entecavir $(3.70 \%)$ therapy in $\mathrm{HBeAg}$-negative patients. Moreover, among patients with baseline HBsAg titers ranging from 100 to $1,500 \mathrm{IU} / \mathrm{mL}$, the HBsAg loss rate was $27.3 \%$ in the combination therapy group (90). These studies suggest that in long-term NAs treated $\mathrm{CHB}$ patients, particularly those with low baseline $\mathrm{HBsAg}$ levels, therapeutic vaccination with conventional HBsAg may enhance HBsAg loss. In a recent study, CHB patients under NAs treatment (and with low HBsAg levels) were selected for a pilot immunization study with Sci-B-Vac ${ }^{\mathrm{TM}}$ (129). Three vaccinated patients developed anti-HBs and were cleared of HBsAg after the vaccination. Though this study only involved a few patients, the result is encouraging and hints at the potential usefulness of this approach.

\section{CONCLUSIONS}

HBV affects more than 250 million people worldwide and represents a major global public health concern. Current antiviral therapies with Peg-IFN and NAs can suppress HBV replication and improve the prognosis of $\mathrm{CHB}$, but they can hardly clear $\mathrm{HBsAg}$ to achieve a functional cure of $\mathrm{CHB}$. During chronic $\mathrm{HBV}$ infection, $\mathrm{HBV}$-specific $\mathrm{T}$-cell and $\mathrm{B}$-cell responses are functionally impaired, which leads to a limited efficacy of Bcell targeting therapeutic vaccination in $\mathrm{CHB}$ patients. A high level of circulating and hepatic HBsAg may contribute to HBVspecific immune tolerance and represents a main obstacle in curing CHB. Declining HBsAg levels were found to be associated with a higher chance to achieve a sustained response in $\mathrm{CHB}$ patients under IFN treatment (130). Moreover, a lower level of serum HBsAg at the end of the NAs treatment was associated with a higher rate of $\mathrm{HBs} \mathrm{Ag}$ loss in $\mathrm{HBeAg}$-negative $\mathrm{CHB}$ patients after cessation of NAs treatment or a switch to Peg-IFN therapy. The reduced HBsAg level in these patients is attributed to the effective removal of $\mathrm{HBV}$ cccDNA in patients and considered to be a useful biomarker. At the same time, a reduced serum HBsAg level may also facilitate the recovery of the host's immune system and help control HBV. Thus, the reduction of HBsAg by siRNA, NAPs, antibody-mediated neutralization, or long-term NAs treatment may overcome HBsAg-specific immune tolerance and optimize the therapeutic efficacy of B-cell targeting vaccination in $\mathrm{CHB}$ patients. Therefore, a sequential combination therapy strategy with antiviral treatment, a reduction of HBsAg, and therapeutic vaccination against envelope proteins may induce the appearance of anti-HBs antibodies and lead to a functional cure for $\mathrm{CHB}$.

\section{AUTHOR CONTRIBUTIONS}

ZM, EZ, and ML designed and wrote the paper. EZ designed and drew the figure. ML, SG, and YX carefully revised the paper.

\section{FUNDING}

This work was supported by grants from the National Natural Science Foundation, China (81401663 and 81771688) and Deutsche Forschungsgemeinschaft (TRR60 and GK1949). 


\section{REFERENCES}

1. Polaris Observatory Collaborators. Global prevalence, treatment, and prevention of hepatitis B virus infection in 2016: a modelling study. Lancet Gastroenterol Hepatol. (2018) 3:383-403. doi: 10.1016/S2468-1253(18)30056-6

2. Revill PA, Chisari FV, Block JM, Dandri M, Gehring AJ, Guo H, et al. A global scientific strategy to cure hepatitis B. Lancet Gastroenterol Hepatol. (2019) 4:545-58. doi: 10.1016/S2468-1253(19)30119-0

3. Bertoletti A, Ferrari C. Adaptive immunity in HBV infection. J Hepatol. (2016) 64(suppl. 1):S71-83. doi: 10.1016/j.jhep.2016.01.026

4. Maini MK, Boni C, Ogg GS, King AS, Reignat S, Lee CK, et al. Direct ex vivo analysis of hepatitis $\mathrm{B}$ virus-specific CD8(+) $\mathrm{T}$ cells associated with the control of infection. Gastroenterology. (1999) 117:1386-96. doi: 10.1016/S0016-5085(99)70289-1

5. Thimme R, Wieland S, Steiger C, Ghrayeb J, Reimann KA, Purcell RH, et al. CD8(+) T cells mediate viral clearance and disease pathogenesis during acute hepatitis B virus infection. J Virol. (2003) 77:68-76. doi: 10.1128/JVI.77.1.68-76.2003

6. Sprengers D, van der Molen RG, Kusters JG, De Man RA, Niesters HG, Schalm SW, et al. Analysis of intrahepatic HBV-specific cytotoxic T-cells during and after acute HBV infection in humans. J Hepatol. (2006) 45:182-9. doi: 10.1016/j.jhep.2005.12.022

7. Fisicaro P, Valdatta C, Massari M, Loggi E, Biasini E, Sacchelli L, et al. Antiviral intrahepatic T-cell responses can be restored by blocking programmed death-1 pathway in chronic hepatitis B. Gastroenterology. (2010) 138:682-93. doi: 10.1053/j.gastro.2009.09.052

8. Bengsch B, Martin B, Thimme R. Restoration of HBV-specific CD8+ T cell function by PD-1 blockade in inactive carrier patients is linked to $\mathrm{T}$ cell differentiation. J Hepatol. (2014) 61:1212-9. doi: 10.1016/j.jhep.2014.07.005

9. Fisicaro P, Barili V, Montanini B, Acerbi G, Ferracin M, Guerrieri F, et al. Targeting mitochondrial dysfunction can restore antiviral activity of exhausted HBV-specific CD8 T cells in chronic hepatitis B. Nat Med. (2017) 23:327-36. doi: 10.1038/nm.4275

10. Burton AR, Pallett LJ, McCoy LE, Suveizdyte K, Amin OE, Swadling L, et al. Circulating and intrahepatic antiviral B cells are defective in hepatitis B. J Clin Invest. (2018) 128:4588-603. doi: 10.1172/JCI121960

11. Salimzadeh L, Le Bert N, Dutertre CA, Gill US, Newell EW, Frey C, et al. PD-1 blockade partially recovers dysfunctional virus-specific B cells in chronic hepatitis B infection. J Clin Invest. (2018) 128:4573-87. doi: 10.1172/JCI121957

12. Le Bert N, Salimzadeh L, Gill US, Dutertre CA, Fachetti F, Tan A, et al. Comparative characterization of B cells specific for HBV nucleocapsid and envelope proteins in patients with chronic hepatitis B. J Hepatol. (2019). doi: 10.1016/j.jhep.2019.07.015. [Epub ahead of print].

13. Yuan Q, Song LW, Cavallone D, Moriconi F, Cherubini B, Colombatto $\mathrm{P}$, et al. Total hepatitis B core antigen antibody, a quantitative noninvasive marker of hepatitis B virus induced liver disease. PLoS ONE. (2015) 10:e130209. doi: 10.1371/journal.pone.0130209

14. Zhou J, Song L, Zhao H, Yan L, Ma A, Xie S, et al. Serum hepatitis B core antibody as a biomarker of hepatic inflammation in chronic hepatitis B patients with normal alanine aminotransferase. Sci Rep. (2017) 7:2747. doi: 10.1038/s41598-017-03102-3

15. Fan R, Sun J, Yuan Q, Xie Q, Bai X, Ning Q, et al. Baseline quantitative hepatitis $\mathrm{B}$ core antibody titre alone strongly predicts HBeAg seroconversion across chronic hepatitis $B$ patients treated with peginterferon or nucleos(t)ide analogues. Gut. (2016) 65:313-20. doi: 10.1136/gutjnl-2014-308546

16. Xu JH, Song LW, Li N, Wang S, Zeng Z, Si CW, et al. Baseline hepatitis $\mathrm{B}$ core antibody predicts treatment response in chronic hepatitis B patients receiving long-term entecavir. J Viral Hepat. (2017) 24:148-54. doi: $10.1111 /$ jvh.12626

17. Cai S, Li Z, Yu T, Xia M, Peng J. Serum hepatitis B core antibody levels predict $\mathrm{HBeAg}$ seroconversion in chronic hepatitis B patients with high viral load treated with nucleos(t)ide analogs. Infect Drug Resist. (2018) 11:469-77. doi: 10.2147/IDR.S163038

18. Terrault NA, Lok ASF, McMahon BJ, Chang KM, Hwang JP, Jonas MM, et al. Update on prevention, diagnosis, and treatment of chronic hepatitis
B: AASLD 2018 hepatitis B guidance. Hepatology. (2018) 67:1560-99. doi: 10.1002/hep. 29800

19. Lok AS, Zoulim F, Dusheiko G, Ghany MG. Hepatitis B cure: from discovery to regulatory approval. Hepatology. (2017) 66:1296-313. doi: 10.1002/hep.29323

20. Loomba R, Liang TJ. Hepatitis B reactivation associated with immune suppressive and biological modifier therapies: current concepts, management strategies, and future directions. Gastroenterology. (2017) 152:1297-309. doi: 10.1053/j.gastro.2017.02.009

21. Kusumoto S, Tanaka Y, Ueda R, Mizokami M. Reactivation of hepatitis $\mathrm{B}$ virus following rituximab-plus-steroid combination chemotherapy. $J$ Gastroenterol. (2011) 46:9-16. doi: 10.1007/s00535-010-0331-4

22. Seto WK, Chan TS, Hwang YY, Wong DK, Fung J, Liu KS, et al. Hepatitis B reactivation in patients with previous hepatitis $\mathrm{B}$ virus exposure undergoing rituximab-containing chemotherapy for lymphoma: a prospective study. $J$ Clin Oncol. (2014) 32:3736-43. doi: 10.1200/JCO.2014.56.7081

23. Paul S, Dickstein A, Saxena A, Terrin N, Viveiros K, Balk EM, et al. Role of surface antibody in hepatitis $\mathrm{B}$ reactivation in patients with resolved infection and hematologic malignancy: a meta-analysis. Hepatology. (2017) 66:379-88. doi: 10.1002/hep.29082

24. Corti D, Benigni F, Shouval D. Viral envelope-specific antibodies in chronic hepatitis B virus infection. Curr Opin Virol. (2018) 30:48-57. doi: 10.1016/j.coviro.2018.04.002

25. Gao Y, Zhang TY, Yuan Q, Xia NS. Antibody-mediated immunotherapy against chronic hepatitis B virus infection. Hum Vaccin Immunother. (2017) 13:1768-73. doi: 10.1080/21645515.2017.1319021

26. Chen HS, Wu JF, Su TH, Chen HL, Hsu HY, Xia NS, et al. Baseline level of hepatitis B core antibody predicts spontaneous HBeAg seroconversion in HBeAg-positive children with a normal ALT level. Hepatology. (2019). doi: 10.1002/hep.30788. [Epub ahead of print].

27. Vanwolleghem T, Hou J, van Oord G, Andeweg AC, Osterhaus AD, Pas SD, et al. Re-evaluation of hepatitis B virus clinical phases by systems biology identifies unappreciated roles for the innate immune response and B cells. Hepatology. (2015) 62:87-100. doi: 10.1002/hep.27805

28. Farci P, Diaz G, Chen Z, Govindarajan S, Tice A, Agulto L, et al. B cell gene signature with massive intrahepatic production of antibodies to hepatitis B core antigen in hepatitis B virus-associated acute liver failure. Proc Natl Acad Sci USA. (2010) 107:8766-71. doi: 10.1073/pnas.1003854107

29. Chen Z, Diaz G, Pollicino T, Zhao H, Engle RE, Schuck P, et al. Role of humoral immunity against hepatitis B virus core antigen in the pathogenesis of acute liver failure. Proc Natl Acad Sci USA. (2018) 115:E11369-78. doi: 10.1073/pnas.1809028115

30. Tuaillon E, Tabaa YA, Petitjean G, Huguet MF, Pajeaux G, Fondere JM, et al. Detection of memory B lymphocytes specific to hepatitis B virus (HBV) surface antigen (HBsAg) from HBsAg-vaccinated or HBVimmunized subjects by ELISPOT assay. J Immunol Methods. (2006) 315:14452. doi: 10.1016/j.jim.2006.07.016

31. Valats JC, Tuaillon E, Funakoshi N, Hoa D, Brabet MC, Bollore K, et al. Investigation of memory B cell responses to hepatitis B surface antigen in health care workers considered as non-responders to vaccination. Vaccine. (2010) 28:6411-6. doi: 10.1016/j.vaccine.2010.07.058

32. Ward SM, Phalora P, Bradshaw D, Leyendeckers H, Klenerman P. Direct ex vivo evaluation of long-lived protective antiviral memory $\mathrm{B}$ cell responses against hepatitis B virus. J Infect Dis. (2008) 198:813-7. doi: 10.1086/591094

33. Neumann-Haefelin C, Thimme R. Entering the spotlight: hepatitis B surface antigen-specific B cells. J Clin Invest. (2018) 128:4257-9. doi: 10.1172/JCI124098

34. Poonia B, Ayithan N, Nandi M, Masur H, Kottilil S. HBV induces inhibitory FcRL receptor on B cells and dysregulates B cell-T follicular helper cell axis. Sci Rep. (2018) 8:15296. doi: 10.1038/s41598-018-33719-x

35. Oliviero B, Cerino A, Varchetta S, Paudice E, Pai S, Ludovisi S, et al. Enhanced B-cell differentiation and reduced proliferative capacity in chronic hepatitis C and chronic hepatitis B virus infections. J Hepatol. (2011) 55:53-60. doi: 10.1016/j.jhep.2010.10.016

36. Xu X, Shang Q, Chen X, Nie W, Zou Z, Huang A, et al. Reversal of Bcell hyperactivation and functional impairment is associated with HBsAg seroconversion in chronic hepatitis B patients. Cell Mol Immunol. (2015) 12:309-16. doi: $10.1038 / \mathrm{cmi} .2015 .25$ 
37. Maruyama T, McLachlan A, Iino S, Koike K, Kurokawa K, Milich DR. The serology of chronic hepatitis B infection revisited. J Clin Invest. (1993) 91:2586-95. doi: 10.1172/JCI116497

38. Pernice W, Sodomann CP, Luben G, Seiler FR, Sedlacek HH. Antigenspecific detection of HBsAG-containing immune complexes in the course of hepatitis B virus infection. Clin Exp Immunol. (1979) 37:376-80.

39. Zhang JM, Xu Y, Wang XY, Yin YK, Wu XH, Weng XH, et al. Coexistence of hepatitis B surface antigen (HBsAg) and heterologous subtype-specific antibodies to HBsAg among patients with chronic hepatitis B virus infection. Clin Infect Dis. (2007) 44:1161-9. doi: 10.1086/513200

40. Lada O, Benhamou Y, Poynard T, Thibault V. Coexistence of hepatitis B surface antigen ( $\mathrm{HBs} \mathrm{Ag}$ ) and anti-HBs antibodies in chronic hepatitis B virus carriers: influence of “a” determinant variants. J Virol. (2006) 80:296875. doi: 10.1128/JVI.80.6.2968-2975.2006

41. Zhang ZH, Li L, Zhao XP, Glebe D, Bremer CM, Zhang ZM, et al. Elimination of hepatitis $B$ virus surface antigen and appearance of neutralizing antibodies in chronically infected patients without viral clearance. J Viral Hepat. (2011) 18:424-33. doi: 10.1111/j.1365-2893.2010.01322.x

42. Beasley RP, Hwang LY, Lin CC, Stevens CE, Wang KY, Sun TS, et al. Hepatitis B immune globulin (HBIG) efficacy in the interruption of perinatal transmission of hepatitis B virus carrier state. Initial report of a randomised double-blind placebo-controlled trial. Lancet. (1981) 2:388-93. doi: 10.1016/S0140-6736(81)90832-1

43. Shouval D, Samuel D. Hepatitis B immune globulin to prevent hepatitis $\mathrm{B}$ virus graft reinfection following liver transplantation: a concise review. Hepatology. (2000) 32:1189-95. doi: 10.1053/jhep.2000.19789

44. van Nunen AB, Baumann M, Manns MP, Reichen J, Spengler U, Marschner JP, et al. Efficacy and safety of an intravenous monoclonal anti-HBs in chronic hepatitis B patients. Liver. (2001) 21:207-12. doi: 10.1034/j.1600-0676.2001.021003207.x

45. Galun E, Eren R, Safadi R, Ashour Y, Terrault N, Keeffe EB, et al. Clinical evaluation (phase I) of a combination of two human monoclonal antibodies to HBV: safety and antiviral properties. Hepatology. (2002) 35:673-9. doi: 10.1053/jhep.2002.31867

46. van Nunen AB, de Man RA, Heijtink RA, Vossen AC, Schalm SW. Passive immunization of chronic hepatitis $B$ patients on lamivudine therapy: a feasible issue? J Viral Hepat. (2002) 9:221-8. doi: 10.1046/j.1365-2893.2002.00337.x

47. Tsuge M, Hiraga N, Uchida T, Kan H, Miyaki E, Masaki K, et al. Antiviral effects of anti-HBs immunoglobulin and vaccine on $\mathrm{HBs}$ antigen seroclearance for chronic hepatitis B infection. J Gastroenterol. (2016) 51:1073-80. doi: 10.1007/s00535-016-1189-x

48. Pol S, Driss F, Michel ML, Nalpas B, Berthelot P, Brechot C. Specific vaccine therapy in chronic hepatitis B infection. Lancet. (1994) 344:342. doi: 10.1016/S0140-6736(94)91384-6

49. Pol S, Nalpas B, Driss F, Michel ML, Tiollais P, Denis J, et al. Efficacy and limitations of a specific immunotherapy in chronic hepatitis B. J Hepatol. (2001) 34:917-21. doi: 10.1016/S0168-8278(01)00028-9

50. Xu DZ, Zhao K, Guo LM, Li LJ, Xie Q, Ren H, et al. A randomized controlled phase IIb trial of antigen-antibody immunogenic complex therapeutic vaccine in chronic hepatitis B patients. PLOS ONE. (2008) 3:e2565. doi: 10.1371/journal.pone.0002565

51. Xu DZ, Wang XY, Shen XL, Gong GZ, Ren H, Guo LM, et al. Results of a phase III clinical trial with an HBsAg-HBIG immunogenic complex therapeutic vaccine for chronic hepatitis B patients: experiences and findings. J Hepatol. (2013) 59:450-6. doi: 10.1016/j.jhep.2013.05.003

52. Boni C, Bertoletti A, Penna A, Cavalli A, Pilli M, Urbani S, et al. Lamivudine treatment can restore $\mathrm{T}$ cell responsiveness in chronic hepatitis B. J Clin Invest. (1998) 102:968-75. doi: 10.1172/JCI3731

53. Boni C, Penna A, Bertoletti A, Lamonaca V, Rapti I, Missale G, et al. Transient restoration of anti-viral $\mathrm{T}$ cell responses induced by lamivudine therapy in chronic hepatitis B. J Hepatol. (2003) 39:595-605. doi: 10.1016/S0168-8278(03)00292-7

54. Boni C, Laccabue D, Lampertico P, Giuberti T, Vigano M, Schivazappa S, et al. Restored function of $\mathrm{HBV}$-specific $\mathrm{T}$ cells after long-term effective therapy with nucleos(t)ide analogues. Gastroenterology. (2012) 143:963-73 e9. doi: 10.1053/j.gastro.2012.07.014
55. Vandepapeliere P, Lau GK, Leroux-Roels G, Horsmans Y, Gane E, Tawandee $\mathrm{T}$, et al. Therapeutic vaccination of chronic hepatitis $\mathrm{B}$ patients with virus suppression by antiviral therapy: a randomized, controlled study of coadministration of HBsAg/AS02 candidate vaccine and lamivudine. Vaccine. (2007) 25:8585-97. doi: 10.1016/j.vaccine.2007.09.072

56. Shouval D, Ilan Y, Adler R, Deepen R, Panet A, Even-Chen Z, et al. Improved immunogenicity in mice of a mammalian cell-derived recombinant hepatitis B vaccine containing pre-S1 and pre-S2 antigens as compared with conventional yeast-derived vaccines. Vaccine. (1994) 12:1453-9. doi: 10.1016/0264-410X(94)90155-4

57. Shapira MY, Zeira E, Adler R, Shouval D. Rapid seroprotection against hepatitis B following the first dose of a Pre-S1/Pre-S2/S vaccine. J Hepatol. (2001) 34:123-7. doi: 10.1016/S0168-8278(00)00082-9

58. Hoa PT, Huy NT, Thu le T, Nga CN, Nakao K, Eguchi K, et al. Randomized controlled study investigating viral suppression and serological response following pre-S1/pre-S2/S vaccine therapy combined with lamivudine treatment in HBeAg-positive patients with chronic hepatitis B. Antimicrob Agents Chemother. (2009) 53:5134-40. doi: 10.1128/AAC.00276-09

59. Mak LY, Seto WK, Fung J, Yuen MF. New biomarkers of chronic hepatitis B. Gut Liver. (2019). doi: 10.5009/gnl18425

60. Testoni B, Lebosse F, Scholtes C, Berby F, Miaglia C, Subic M, et al. Serum hepatitis B core-related antigen ( $\mathrm{HBcrAg}$ ) correlates with covalently closed circular DNA transcriptional activity in chronic hepatitis B patients. $J$ Hepatol. (2019) 70:615-25. doi: 10.1016/j.jhep.2018.11.030

61. Chen EQ, Wang ML, Tao YC, Wu DB, Liao J, He M, et al. Serum HBcrAg is better than HBV RNA and HBsAg in reflecting intrahepatic covalently closed circular DNA. J Viral Hepat. (2019) 26:586-95. doi: 10.1111/jvh.13061

62. Hosaka T, Suzuki F, Kobayashi M, Fujiyama S, Kawamura Y, Sezaki H, et al. Impact of hepatitis B core-related antigen on the incidence of hepatocellular carcinoma in patients treated with nucleos(t)ide analogues. Aliment Pharmacol Ther. (2019) 49:457-71. doi: 10.1111/apt.15108

63. To WP, Mak LY, Wong DK, Fung J, Liu F, Seto WK, et al. Hepatitis B core-related antigen levels after $\mathrm{HBeAg}$ seroconversion is associated with the development of hepatocellular carcinoma. J Viral Hepat. (2019). doi: 10.1111/jvh.13191. [Epub ahead of print].

64. Chan HL, Thompson A, Martinot-Peignoux M, Piratvisuth T, Cornberg M, Brunetto MR, et al. Hepatitis B surface antigen quantification: why and how to use it in 2011 - a core group report. J Hepatol. (2011) 55:1121-31. doi: 10.1016/j.jhep.2011.06.006

65. Tseng TC, Kao JH. Clinical utility of quantitative HBsAg in natural history and nucleos(t)ide analogue treatment of chronic hepatitis $\mathrm{B}$ : new trick of old dog. J Gastroenterol. (2013) 48:13-21. doi: 10.1007/s00535-0120668-y

66. Cornberg M, Wong VW, Locarnini S, Brunetto M, Janssen HLA, Chan HL. The role of quantitative hepatitis B surface antigen revisited. J Hepatol. (2017) 66:398-411. doi: 10.1016/j.jhep.2016.08.009

67. Kondo Y, Ninomiya M, Kakazu E, Kimura O, Shimosegawa T. Hepatitis $\mathrm{B}$ surface antigen could contribute to the immunopathogenesis of hepatitis B virus infection. ISRN Gastroenterol. (2013) 2013:935295. doi: $10.1155 / 2013 / 935295$

68. Dembek C, Protzer U, Roggendorf M. Overcoming immune tolerance in chronic hepatitis B by therapeutic vaccination. Curr Opin Virol. (2018) 30:58-67. doi: 10.1016/j.coviro.2018.04.003

69. Tsai KN, Kuo CF, Ou JJ. Mechanisms of hepatitis B virus persistence. Trends Microbiol. (2018) 26:33-42. doi: 10.1016/j.tim.2017.07.006

70. Wu J, Meng Z, Jiang M, Pei R, Trippler M, Broering R, et al. Hepatitis $B$ virus suppresses toll-like receptor-mediated innate immune responses in murine parenchymal and nonparenchymal liver cells. Hepatology. (2009) 49:1132-40. doi: 10.1002/hep.22751

71. Jiang M, Broering R, Trippler M, Poggenpohl L, Fiedler M, Gerken G, et al. Toll-like receptor-mediated immune responses are attenuated in the presence of high levels of hepatitis B virus surface antigen. J Viral Hepat. (2014) 21:860-72. doi: 10.1111/jvh.12216

72. Op den Brouw ML, Binda RS, van Roosmalen MH, Protzer U, Janssen HL, van der Molen RG, et al. Hepatitis B virus surface antigen impairs myeloid dendritic cell function: a possible immune escape mechanism of hepatitis B virus. Immunology. (2009) 126:280-9. doi: 10.1111/j.1365-2567.2008.02896.x 
73. Gehring AJ, Haniffa M, Kennedy PT, Ho ZZ, Boni C, Shin A, et al. Mobilizing monocytes to cross-present circulating viral antigen in chronic infection. J Clin Invest. (2013) 123:3766-76. doi: 10.1172/JCI66043

74. Webster GJ, Reignat S, Brown D, Ogg GS, Jones L, Seneviratne SL, et al. Longitudinal analysis of $\mathrm{CD} 8+\mathrm{T}$ cells specific for structural and nonstructural hepatitis $B$ virus proteins in patients with chronic hepatitis B: implications for immunotherapy. J Virol. (2004) 78:5707-19. doi: 10.1128/JVI.78.11.5707-5719.2004

75. Boni C, Fisicaro P, Valdatta C, Amadei B, Di Vincenzo P, Giuberti $\mathrm{T}$, et al. Characterization of hepatitis B virus (HBV)-specific T-cell dysfunction in chronic HBV infection. J Virol. (2007) 81:4215-25. doi: 10.1128/JVI.02844-06

76. Schmidt J, Blum HE, Thimme R. T-cell responses in hepatitis B and C virus infection: similarities and differences. Emerg Microbes Infect. (2013) 2:e15. doi: 10.1038/emi.2013.14

77. Fang Z, Li J, Yu X, Zhang D, Ren G, Shi B, et al. Polarization of monocytic myeloid-derived suppressor cells by hepatitis B surface antigen is mediated via ERK/IL-6/STAT3 signaling feedback and restrains the activation of T cells in chronic hepatitis B virus infection. J Immunol. (2015) 195:4873-83. doi: 10.4049/jimmunol.1501362

78. Pal S, Nandi M, Dey D, Chakraborty BC, Shil A, Ghosh S, et al. Myeloidderived suppressor cells induce regulatory $\mathrm{T}$ cells in chronically $\mathrm{HBV}$ infected patients with high levels of hepatitis B surface antigen and persist after antiviral therapy. Aliment Pharmacol Ther. (2019) 49:1346-59. doi: 10.1111/apt.15226

79. Kosinska AD, Pishraft-Sabet L, Wu W, Fang Z, Lenart M, Chen J, et al. Low hepatitis B virus-specific T-cell response in males correlates with high regulatory T-cell numbers in murine models. Hepatology. (2017) 66:69-83. doi: $10.1002 /$ hep. 29155

80. Takkenberg RB, Jansen L, de Niet A, Zaaijer HL, Weegink CJ, Terpstra $\mathrm{V}$, et al. Baseline hepatitis B surface antigen ( $\mathrm{HBsAg}$ ) as predictor of sustained HBsAg loss in chronic hepatitis B patients treated with pegylated interferon-alpha2a and adefovir. Antivir Ther. (2013) 18:895-904. doi: 10.3851/IMP2580

81. Cao Z, Liu Y, Ma L, Lu J, Jin Y, Ren S, et al. A potent hepatitis B surface antigen response in subjects with inactive hepatitis B surface antigen carrier treated with pegylated-interferon alpha. Hepatology. (2017) 66:1058-66. doi: 10.1002/hep.29213

82. Huang J, Zhang K, Chen W, Liao J, Luo X, Chen R. Switching to PegIFNalpha-2b leads to HBsAg loss in patients with low HBsAg levels and HBV DNA suppressed by NAs. Sci Rep. (2017) 7:13383. doi: 10.1038/s41598-017-13747-9

83. Ning Q, Han M, Sun Y, Jiang J, Tan D, Hou J, et al. Switching from entecavir to PegIFN alfa-2a in patients with HBeAg-positive chronic hepatitis B: a randomised open-label trial (OSST trial). J Hepatol. (2014) 61:777-84. doi: 10.1016/j.jhep.2014.05.044

84. Hadziyannis SJ, Sevastianos V, Rapti I, Vassilopoulos D, Hadziyannis E. Sustained responses and loss of HBsAg in HBeAg-negative patients with chronic hepatitis B who stop long-term treatment with adefovir. Gastroenterology. (2012) 143:629-36 e1. doi: 10.1053/j.gastro.2012.05.039

85. Jeng WJ, Chen YC, Chien RN, Sheen IS, Liaw YF. Incidence and predictors of hepatitis B surface antigen seroclearance after cessation of nucleos(t)ide analogue therapy in hepatitis B e antigen-negative chronic hepatitis B. Hepatology. (2018) 68:425-34. doi: 10.1002/hep.29640

86. Seto WK, Liu K, Wong DK, Fung J, Huang FY, Hung IF, et al. Patterns of hepatitis B surface antigen decline and HBV DNA suppression in Asian treatment-experienced chronic hepatitis B patients after three years of tenofovir treatment. J Hepatol. (2013) 59:709-16. doi: 10.1016/j.jhep.2013.06.007

87. Chevaliez S, Hezode C, Bahrami S, Grare M, Pawlotsky JM. Long-term hepatitis B surface antigen ( $\mathrm{HBsAg}$ ) kinetics during nucleoside/nucleotide analogue therapy: finite treatment duration unlikely. J Hepatol. (2013) 58:676-83. doi: 10.1016/j.jhep.2012.11.039

88. Qiu K, Liu B, Li SY, Li H, Chen ZW, Luo AR, et al. Systematic review with meta-analysis: combination treatment of regimens based on pegylated interferon for chronic hepatitis B focusing on hepatitis B surface antigen clearance. Aliment Pharmacol Ther. (2018) 47:1340-8. doi: 10.1111/apt.14629
89. Yeo YH, Ho HJ, Yang HI, Tseng TC, Hosaka T, Trinh HN, et al. Factors associated with rates of HBsAg seroclearance in adults with chronic HBV infection: a systematic review and meta-analysis. Gastroenterology. (2019) 156:635-46 e9. doi: 10.1053/j.gastro.2018.10.027

90. Wu D, Wang P, Han M, Chen Y, Chen X, Xia Q, et al. Sequential combination therapy with interferon, interleukin-2 and therapeutic vaccine in entecavirsuppressed chronic hepatitis B patients: the Endeavor study. Hepatol Int. (2019) 13:573-86. doi: 10.1007/s12072-019-09956-1

91. Stelma F, de Niet A, Tempelmans Plat-Sinnige MJ, Jansen L, Takkenberg RB, Reesink HW, et al. Natural killer cell characteristics in patients with chronic hepatitis $B$ virus $(\mathrm{HBV})$ infection are associated with $\mathrm{HBV}$ surface antigen clearance after combination treatment with pegylated interferon alfa-2a and adefovir. J Infect Dis. (2015) 212:1042-51. doi: 10.1093/infdis/jiv180

92. Cannizzo ES, Tincati C, Binda F, Ronzi P, Cazzaniga FA, Antinori S, et al. Unconventional $\mathrm{T}$ cells in chronic hepatitis $\mathrm{B}$ patients on long-term suppressive therapy with tenofovir followed by a Peg-IFN add-on strategy: a randomized study. J Viral Hepat. (2018) 25:381-90. doi: 10.1111/jvh.12820

93. Zimmer CL, Rinker F, Honer Zu Siederdissen C, Manns MP, Wedemeyer $\mathrm{H}$, Cornberg $\mathrm{M}$, et al. Increased NK cell function after cessation of longterm nucleos(t)ide analogue treatment in chronic hepatitis B is associated with liver damage and HBsAg loss. I Infect Dis. (2018) 217:1656-66. doi: 10.1093/infdis/jiy097

94. Rinker F, Zimmer CL, Honer Zu Siederdissen C, Manns MP, Kraft ARM, Wedemeyer $\mathrm{H}$, et al. Hepatitis $\mathrm{B}$ virus-specific $\mathrm{T}$ cell responses after stopping nucleos(t)ide analogue therapy in $\mathrm{HBeAg}$-negative chronic hepatitis B. $J$ Hepatol. (2018) 69:584-93. doi: 10.1016/j.jhep.2018.05.004

95. Dusheiko G, Wang B. Hepatitis B surface antigen loss: too little, too late and the challenge for the future. Gastroenterology. (2019) 156:548-51. doi: 10.1053/j.gastro.2019.01.015

96. Gish RG, Yuen MF, Chan HL, Given BD, Lai CL, Locarnini SA, et al. Synthetic RNAi triggers and their use in chronic hepatitis B therapies with curative intent. Antiviral Res. (2015) 121:97-108. doi: 10.1016/j.antiviral.2015.06.019

97. Wooddell CI, Yuen MF, Chan HL, Gish RG, Locarnini SA, Chavez D, et al. RNAi-based treatment of chronically infected patients and chimpanzees reveals that integrated hepatitis B virus DNA is a source of HBsAg. Sci Transl Med. (2017) 9:eaan0241. doi: 10.1126/scitranslmed.aan0241

98. Turner AM, Stolk J, Bals R, Lickliter JD, Hamilton J, Christianson DR, et al. Hepatic-targeted RNA interference provides robust and persistent knockdown of alpha-1 antitrypsin levels in ZZ patients. J Hepatol. (2018) 69:378-84. doi: 10.1016/j.jhep.2018.03.012

99. Vaillant A. Nucleic acid polymers: broad spectrum antiviral activity, antiviral mechanisms and optimization for the treatment of hepatitis B and hepatitis D infection. Antiviral Res. (2016) 133:32-40. doi: 10.1016/j.antiviral.2016.07.004

100. Vaillant A. REP 2139: antiviral mechanisms and applications in achieving functional control of HBV and HDV infection. ACS Infect Dis. (2019) 5:675-87. doi: 10.1021/acsinfecdis.8b00156

101. Al-Mahtab M, Bazinet M, Vaillant A. Safety and efficacy of nucleic acid polymers in monotherapy and combined with immunotherapy in treatmentnaive bangladeshi patients with $\mathrm{HBeAg}+$ chronic hepatitis B infection. PLoS ONE. (2016) 11:e0156667. doi: 10.1371/journal.pone.0156667

102. Bazinet M, Pantea V, Cebotarescu V, Cojuhari L, Jimbei P, Albrecht J, et al. Safety and efficacy of REP 2139 and pegylated interferon alfa-2a for treatment-naive patients with chronic hepatitis $B$ virus and hepatitis D virus co-infection (REP 301 and REP 301-LTF): a non-randomised, open-label, phase 2 trial. Lancet Gastroenterol Hepatol. (2017) 2:877-89. doi: 10.1016/S2468-1253(17)30288-1

103. Wang W, Sun L, Li T, Ma Y, Li J, Liu Y, et al. A human monoclonal antibody against small envelope protein of hepatitis B virus with potent neutralization effect. MAbs. (2016) 8:468-77. doi: 10.1080/19420862.2015.1134409

104. Li D, He W, Liu X, Zheng S, Qi Y, Li H, et al. A potent human neutralizing antibody Fc-dependently reduces established HBV infections. Elife. (2017) 6:e26738. doi: 10.7554/eLife.26738

105. Zhang TY, Yuan Q, Zhao JH, Zhang YL, Yuan LZ, Lan Y, et al. Prolonged suppression of HBV in mice by a novel antibody that targets a unique epitope on hepatitis B surface antigen. Gut. (2016) 65:658-71. doi: 10.1136/gutjnl-2014-308964 
106. Zhang TY, Guo XR, Wu YT, Kang XZ, Zheng QB, Qi RY, et al. A unique B cell epitope-based particulate vaccine shows effective suppression of hepatitis B surface antigen in mice. Gut. (2019). doi: 10.1136/gutjnl-2018-317725. [Epub ahead of print].

107. Lee YB, Lee JH, Kim YJ, Yoon JH, Lee HS. The effect of therapeutic vaccination for the treatment of chronic hepatitis B virus infection. J Med Virol. (2015) 87:575-82. doi: 10.1002/jmv.24091

108. Zuckerman JN, Zuckerman AJ, Symington I, Du W, Williams A, Dickson $\mathrm{B}$, et al. Evaluation of a new hepatitis $\mathrm{B}$ triple-antigen vaccine in inadequate responders to current vaccines. Hepatology. (2001) 34:798-802. doi: 10.1053/jhep.2001.27564

109. Yalcin K, Danis R, Degertekin H, Alp MN, Tekes S, Budak T. The lack of effect of therapeutic vaccination with a pre-S2/S HBV vaccine in the immune tolerant phase of chronic HBV infection. J Clin Gastroenterol. (2003) 37:330-5. doi: 10.1097/00004836-200310000-00012

110. Yalcin K, Acar M, Degertekin H. Specific hepatitis B vaccine therapy in inactive HBsAg carriers: a randomized controlled trial. Infection. (2003) 31:221-5. doi: 10.1007/s15010-003-3187-1

111. Helvaci M, Kizilgunesler A, Kasirga E, Ozbal E, Kuzu M, Sozen G. Efficacy of hepatitis B vaccination and interferon-alpha-2b combination therapy versus interferon-alpha-2b monotherapy in children with chronic hepatitis B. J Gastroenterol Hepatol. (2004) 19:785-91. doi: 10.1111/j.1440-1746.2004.03358.x

112. Betancourt AA, Delgado CA, Estevez ZC, Martinez JC, Rios GV, AureolesRosello SR, et al. Phase I clinical trial in healthy adults of a nasal vaccine candidate containing recombinant hepatitis B surface and core antigens. Int J Infect Dis. (2007) 11:394-401. doi: 10.1016/j.ijid.2006.09.010

113. Al-Mahtab M, Akbar SM, Aguilar JC, Uddin MH, Khan MS, Rahman S. Therapeutic potential of a combined hepatitis B virus surface and core antigen vaccine in patients with chronic hepatitis B. Hepatol Int. (2013) 7:981-9. doi: 10.1007/s12072-013-9486-4

114. Al Mahtab M, Akbar SMF, Aguilar JC, Guillen G, Penton E, Tuero A, et al. Treatment of chronic hepatitis $B$ naive patients with a therapeutic vaccine containing $\mathrm{HBs}$ and $\mathrm{HBc}$ antigens (a randomized, open and treatment controlled phase III clinical trial). PLoS ONE. (2018) 13:e0201236. doi: 10.1371/journal.pone. 0201236

115. Suthers AN, Sarantopoulos S. TLR7/TLR9- and B cell receptor-signaling crosstalk: promotion of potentially dangerous B cells. Front Immunol. (2017) 8:775. doi: 10.3389/fimmu.2017.00775

116. Bessa J, Kopf M, Bachmann MF. Cutting edge: IL-21 and TLR signaling regulate germinal center responses in a B cell-intrinsic manner. J Immunol. (2010) 184:4615-9. doi: 10.4049/jimmunol.0903949

117. Castiblanco DP, Maul RW, Russell Knode LM, Gearhart PJ. Co-stimulation of BCR and Toll-like receptor 7 increases somatic hypermutation, memory $\mathrm{B}$ cell formation, and secondary antibody response to protein antigen. Front Immunol. (2017) 8:1833. doi: 10.3389/fimmu.2017.01833

118. Jegerlehner A, Maurer P, Bessa J, Hinton HJ, Kopf M, Bachmann MF. TLR9 signaling in B cells determines class switch recombination to IgG2a. J Immunol. (2007) 178:2415-20. doi: 10.4049/jimmunol.178.4.2415

119. Hou B, Saudan P, Ott G, Wheeler ML, Ji M, Kuzmich L, et al. Selective utilization of Toll-like receptor and MyD88 signaling in B cells for enhancement of the antiviral germinal center response. Immunity. (2011) 34:375-84. doi: 10.1016/j.immuni.2011.01.011

120. Ma Z, Zhang E, Yang D, Lu M. Contribution of Toll-like receptors to the control of hepatitis $B$ virus infection by initiating antiviral innate responses and promoting specific adaptive immune responses. Cell Mol Immunol. (2015) 12:273-82. doi: 10.1038/cmi.2014.112
121. Cooper CL, Davis HL, Morris ML, Efler SM, Adhami MA, Krieg AM, et al. CPG 7909, an immunostimulatory TLR9 agonist oligodeoxynucleotide, as adjuvant to Engerix-B HBV vaccine in healthy adults: a double-blind phase I/II study. J Clin Immunol. (2004) 24:693-701. doi: 10.1007/s10875-004-6244-3

122. Siegrist CA, Pihlgren M, Tougne C, Efler SM, Morris ML, AlAdhami MJ, et al. Co-administration of $\mathrm{CpG}$ oligonucleotides enhances the late affinity maturation process of human anti-hepatitis B vaccine response. Vaccine. (2004) 23:615-22. doi: 10.1016/j.vaccine.2004.07.014

123. Halperin SA, Ward B, Cooper C, Predy G, Diaz-Mitoma F, Dionne $\mathrm{M}$, et al. Comparison of safety and immunogenicity of two doses of investigational hepatitis B virus surface antigen co-administered with an immunostimulatory phosphorothioate oligodeoxyribonucleotide and three doses of a licensed hepatitis B vaccine in healthy adults 1855 years of age. Vaccine. (2012) 30:2556-63. doi: 10.1016/j.vaccine.2012. 01.087

124. Halperin SA, Dobson S, McNeil S, Langley JM, Smith B, McCall-Sani R, et al. Comparison of the safety and immunogenicity of hepatitis B virus surface antigen co-administered with an immunostimulatory phosphorothioate oligonucleotide and a licensed hepatitis B vaccine in healthy young adults. Vaccine. (2006) 24:20-6. doi: 10.1016/j.vaccine.2005.08.095

125. Cooper C, Mackie D. Hepatitis B surface antigen-1018 ISS adjuvantcontaining vaccine: a review of HEPLISAV safety and efficacy. Expert Rev Vaccines. (2011) 10:417-27. doi: 10.1586/erv.10.162

126. Cooper CL, Davis HL, Angel JB, Morris ML, Elfer SM, Seguin I, et al. CPG 7909 adjuvant improves hepatitis B virus vaccine seroprotection in antiretroviral-treated HIV-infected adults. AIDS. (2005) 19:1473-9. doi: 10.1097/01.aids.0000183514.37513.d2

127. Cooper CL, Angel JB, Seguin I, Davis HL, Cameron DW. CPG 7909 adjuvant plus hepatitis B virus vaccination in HIV-infected adults achieves longterm seroprotection for up to 5 years. Clin Infect Dis. (2008) 46:1310-4. doi: $10.1086 / 533467$

128. Lai MW, Hsu CW, Lin CL, Chien RN, Lin WR, Chang CS, et al. Multiple doses of hepatitis B recombinant vaccine for chronic hepatitis B patients with low surface antigen levels: a pilot study. Hepatol Int. (2018) 12:456-64. doi: $10.1007 / \mathrm{s} 12072-018-9890-\mathrm{x}$

129. Roggendorf H KA, Lindemann M, Shouval D, Michler T, Roggendorf M, Gerken G. Induction of functional control in chronic hepatitis B patients with low level HBsAg using a combination of a PreS1/S2/S HBV vaccine (Sci-BVac ${ }^{\mathrm{TM}}$ ) and a nucleoside analogue. J Infect Dis Ther. (2019) 7:389. doi: 10.4172/2332-0877.1000390

130. Sonneveld MJ, Rijckborst V, Boucher CA, Hansen BE, Janssen HL. Prediction of sustained response to peginterferon alfa- $2 \mathrm{~b}$ for hepatitis $\mathrm{B}$ e antigenpositive chronic hepatitis B using on-treatment hepatitis B surface antigen decline. Hepatology. (2010) 52:1251-7. doi: 10.1002/hep.23844

Conflict of Interest: The authors declare that the research was conducted in the absence of any commercial or financial relationships that could be construed as a potential conflict of interest.

Copyright ( 2019 Ma, Zhang, Gao, Xiong and Lu. This is an open-access article distributed under the terms of the Creative Commons Attribution License (CC BY). The use, distribution or reproduction in other forums is permitted, provided the original author(s) and the copyright owner(s) are credited and that the original publication in this journal is cited, in accordance with accepted academic practice. No use, distribution or reproduction is permitted which does not comply with these terms. 